IJSSC: Indonesian Journal of Sport Science and Coaching

Vol. 1 No. 1 Febaruari 2019

Available on: https://online-journal.unja.ac.id/IJSSC

\title{
PENGARUH SENAM AEROBIC TERHADAP TINGKAT KEBUGARAN JASMANI SISWA PUTRA KELAS VIII SMP NEGERI 10 MUARO JAMBI
}

\author{
Sukendro, Triadi Santoso \\ Program Keolahragaan, Universitas Jambi. Jambi \\ Email Korespondensi: sukendrodasar@yahoo.co.id
}

\begin{abstract}
ABSTRAK
Olahraga merupakan bagian dari kehidupan manusia. Dalam melaksanakan olahraga manusia mempunyai tujuan yang berbeda, hal ini karena masing-masing manusia melakukan olahraga sesuai dengan tujuan yang diinginkannya. Daya tahan kardiovaskuler merupakan suatu komponen fisik yang dominan dibutuhkan dalam prestasi olahraga dengan menyesuaikan bentuk latihannya. Dalam cabang olahraga, latihan senam aerobic adalah latihan yang dapat memberikan kontribusi yang baik dalam upaya peningkatan Kebugaran Sasmani Seseorang. Penelitian ini bertujuan untuk mengetahui Pengaruh Latihan Senam Aerobic Tingkat Kebugaran Jamani Siswa Kelas VIII SMP Negeri 10 Muaro Jambi. Metode penelitian yang digunakan adalah Metode Eksperiment Reasearch penelitian ini menggunakan rancangan One Group Preetest-Postest design. Dengan populasi seluruh Siswa Putra Kelas VIII D SMP Negeri 10 Muaro Jambi.dengan jumlah populasi 21 orang dan teknik pengambilan sampel yang digunakan adalah random sampling, dengan jumlah sampel 14 orang, adapun tes yang digunakan adalah TKJI (Test Kebugaran Jasmani Indonesia). Hasil analisis data uji-t, yang diolah secara manual menunjukan bahwa terdapat Pengaruh Latihan Senam Aerobic Terhadap Tingkat Kebugaran Jasmani Siswa Putra Kelas VIII SMP Negeri 10 Muaro Jambi. Hasil Uji-t untuk taraf nyata $\alpha=0.05$ dengan derajad kebebasan $(\mathrm{dk})=(\mathrm{n}-1)=13$ diperoleh $t_{\text {hitung }}(11,55)>t_{\text {tabel }}(1,771)$ berarti hipotesi Ha diterima dan Ho ditolak. Berdasarkan hasil penelitian dapat disimpulkan bahwa Terdapat Pengaruh Yang Signifikan Dari Latihan Senam Aerobic Terhadap kebugaran jasmani Siswa Putra Kelas VIII SMP Negeri 10 Muaro Jambi.

Kata Kunci : Latihan Senam Aerobic, Kebugaran Jasmani,
\end{abstract}

\section{ABSTRACT}

Sports are part of human life. In doing sports, humans have different goals, this is because each human being does sports according to the goals he wants. Cardiovascular endurance is the dominant physical component needed in achieving sports by adjusting the form of exercise. In sports, aerobic exercise is an exercise that can make a good contribution in an effort to increase physical income. Aerobics Gymnastics Jamani Level Fitness Class VIII Students of Muaro Jambi State Middle 10. The research method used was the Experimental Method. This study uses the design of One Group Preetest-Postest design. With a population of all male students of Class VIII D SMP Negeri 10 Muaro Jambi. With a population of 21 people and the sampling technique used was random sampling, with a sample of 14 people, while the test used was TKJI (Indonesian Physical Fitness Test). The results of the t-test data analysis, which were processed manually showed the effect of Aerobic Gymnastics Exercises on the Level of Physical Fitness of Students in Class VIII of Muaro Jambi State Junior High School 10. The results of the $t$-test for the real level $\alpha=0.05$ with the degree of freedom $(d k)=(n-1)=13$ obtained tcount $(11.55)>$ ttable (1.771) means that the hypotesis Ha is accepted and Ho is rejected. Based on the results of the study it can be concluded that there is a significant effect of aerobic exercise on physical fitness of male students of class VIII of Muaro Jambi 10th Middle School.

Keywords: Aerobic Gymnastics Exercise, Physical Fitness, 
IJSSC: Indonesian Journal of Sport Science and Coaching

Vol. 1 No. 1 Febaruari 2019

Available on: https://online-journal.unja.ac.id/IJSSC

\section{Pendahuluan}

Olahraga adalah serangkaian gerak raga yang teratur dan terencana untuk memelihara gerak (yang berarti mempertahankan hidup) dan meningkatkan kemampuan gerak (yang berarti meningkatkan kualitas hidup). Seperti halnya makan, gerak (Olahraga) merupakan kebutuhan hidup yang sifatnya terus-menerus, artinya olahraga sebagai alat untuk mempertahankan hidup, memeliharan dan membina kesehatan, tidak dapat ditinggalkan. Olahraga pun hanya dapat dinikmati dan bermanfaat bagi kesehatan hanya pada mereka yang melakukan kegiatan olahraga. Bila orang hanya menonton olahraga maka sama halnya dengan orang yang hanya menonton orang makan, artinya ia tidak akan bisa merasakan nikmatnya berolahraga dan tidak akan dapat memperoleh manfaat dari olahraga bagi kesehatannya. Hal ini sesuai dengan Undang-Undang Sistem Keolahragaan Nasional No. 3 tahun 2005 pasal 4 tentang dasar, fungsi dan tujuan olahraga, yaitu :

"Keolahragaan bertujuan memelihara dan meningkatkan kesehatan dan kebugaran, prestasi, kualitas manusia, menanamkan nilai moral dan akhlak mulia, sportifitas, disiplin, mempererat dan membina persatuan dan kesatuan bangsa, memperkukuh ketahanan nasional serta mengangkat harkat, martabat dan kehormatan bangsa”.

Olahraga merupakan alat untuk merangsang pertumbuhan dan perkembangan fungsional jasmani, rohani, dan sosial. Tetapi masih banyak orang yang belum menyadarinya, banyak penyakit yang bersumber dari pola hidup yang salah, seperti kurang bergerak dan berolahraga, serta kurang istirahat dan lupa makan. Orang orang yang beralasan, mereka selalu sibuk untuk berolahraga. Padahal olahraga sangat dibutuhkan.

Pendidikan jasmani yang diajarkan disekolah memiliki peranan yang sangat penting, yaitu memberikan kesempatan pada anak didik untuk terlibat langsung dalam berbagai pengalaman belajar melalui aktifitas kebugaran jasmani, olahraga dan kesehatan yang terpilih yang dilakukan secara sistemmatika. Pembekalan pengalaman belajar maupun latihan-latihan fisik dalam olahraga, ini diarahkan untuk membina pertumbuhan fisik dan pengembangan psikis yang lebih baik, sekaligus membentuk kebugaran yang bagus terutama sekali yang terjadi di SMP Negeri 10 Muaro Jambi khususnya.

Dalam hal ini tidak semua guru penjas menyadari hal tersebut, sehingga banyak anggapan bahwa pendidikan jasmani boleh dilaksanakan secara serampangan. Hal ini tercermin dari berbagai gambaran negatif tentang pembelajaran pendididkan jasmani, mulai dari kelemahan proses yang menetap misalnya membiarkan anak melakukan kegiatan olahraga secara bebas, serta tidak menuju pada pembentukan kondisi fisik kebugarannya, namun bagaimana meningkatkan kebugaran siswa, guna untuk menunjang pembentukan kondisi fisik siswa dalam melakukan kegiatan berolahraga.

Fungsi Kebugaran Jasmani adalah untuk mengembangkan kesanggupan dan kemampuaan setiap manusia yang berguna untuk mempertinggi daya kerja. Fungsi kebugaran jasmani dapat dibagi menjadi dua bagian yaitu secara umum untuk mengembangkan kekuatan, kemampuaan, kesanggupan daya reakasi dan daya tahan setiap manusia untuk mempertinggi daya kerja dalam Pembangunan dan Pertahanan Bangsa dan Negara, dan secara khusus Kebugaran jasmani bagi anak-anak untuk pertumbuhan dan perkembangan serta peningkatan prestasi belajar. 
IJSSC: Indonesian Journal of Sport Science and Coaching

Vol. 1 No. 1 Febaruari 2019

Available on: https://online-journal.unja.ac.id/IJSSC

Dalam upaya peningkatan kebugaran jasmani (Saputro dan Suherman dalam Gusril, 2004:124) menyatakan bahwa untuk mendapatkan kebugaran jasmani: 1) dosis latihan, 2) lama latihan, 3) frekuensi latihan. Intensitas latihan kebugaran jasmani berkisar antara $72-78 \%$ dari denyut nadi maksimal (220-umur) disebut training zone. Untuk peningkatan dan pemeliharaan kebugaran jasmani tidak terlepas dari latihan jasmani yanng membina keseimbangan unsur kesegaran jasmani, guna membina dan memelihara kesegaran jasmani, salah satu cara yang dilakukan yaitu latihan yang dapat manigkatkan fisik atau latihan jasmani

Pusat pengembangan kualitas jasmani departemen pendidikan nasional : 2003 menerangkan ada lima komponen tes yang harus diketahui guna untuk menilai tingkat kebugaran jasmani seseorang pada usia 13 - 15 tahun. Komponen tersebut adalah seperti Kecepatan, Kekuatan, Daya Tahan, Kekuatan/Daya Ledak, Daya Tahan Jantung (Cardiovaskular).

Berdasarkan hal yang terjadi di lapangan bahwa peningkatan kemampuan fisik siswa SMP Negeri 10 Muaro Jambi khususnya pada tingkat kebugarannya masih rendah karena banyak siswa yang merasa cepat lelah saat melakukan kegiatan olahraga, dan tidak sedikit siswa yang tidak memencapai garis finis pada saat pengambilan nilai lari jarak menengah, ingin cepat selesai dalam melakukan kegiatan berolahraga, sementara derajat kebugaran jasmani seseorang sangat menetukan kemampuan fisiknya dalam melaksanakan tugas-tugasnya sehari-hari. Semakin tinggi derajat kebugaran seseorang, kian tinggi pula kemampuan kerja fisiknya. Dengan kata lain hasil kerja kian produktif jika kebugaran jasmaninya kian meningkat, dengan melakukan latihan olahraga yang teratur dan terukur, seseorang dapat memiliki berat badan yang ideal, serta dapat meningkatkan kesehatan dan kebugaran jasmani. Banyak olahraga yang dapat dilakukan salah satunya dengan senam aerobic. Senam aerobic adalah kegiatan latihan aerobic yang diberikan dalam bentuk gerakan-gerakan senam.

Sumosardjono (1996: 18), menyatakan latihan senam aerobic penting karena: "Latihan senam aerobic dapat meningkatkan kerja jantung, paru-paru yang efektif, peredaran darah yang baik, sehingga yang bersangkutan dapat bekerja secara kontinu tanpa megalami kelelahan yang berlebihan. Pada sisi lain, senam aerobic juga dapat mengurangi lemak dan menjaga kesegaran serta kebugaran pesertanya”.

Keuntungan melakukan latihan senam aerobik salah satunya dapat meningkatkan kebugan bagi tubuh, dengan intensitas yang dibutuhkan dan waktu yang diperlukan berkisar antara 45 - 60 menit, sehingga dapat dilakukan oleh semua kalangan mulai dari anak - anak sampai mereka yang berusia lanjut.

Selain keterampilan, pembentukan kondisi fisik adalah salah satu hal penting yang harus dimiliki siswa dalam kegiatan berolahraga. Sebab dalam berolahraga, tubuh dituntut aktif bergerak serta mempunyai fisik yang prima. siswa akan kesulitan untuk mengembangkan keterampilan olahraga jika tidak memiliki kondisi fisik yang baik.

Berdasarkan pengamatan penulis melihat kondisi dilapangan bahwa tingkat kebugaran Siswa SMP Negeri 10 Muaro Jambi masih sangat jauh dari harapan yang di lihat ketika mereka melakukan kegiatan berolahraga, Merasa cepat lelah saat berolahraga, dan tidak sedikit siswa yang tidak memencapai garis finis pada saat pengambilan nilai lari jarak menengah, sementara latihan untuk meningkatkan kebugaran mereka hanya dengan latihan lari mengelilingi lapangan halam sekolah beberapa kali putaran, ini mereka lakukan setiap sebelum melakukan kegiatan berolahraga, belum ada variasi latihan lain yang mereka terima untuk meningkatkan kebugaran pada diri mereka. 
IJSSC: Indonesian Journal of Sport Science and Coaching

Vol. 1 No. 1 Febaruari 2019

Available on: https://online-journal.unja.ac.id/IJSSC

Oleh karena itu penulis tertarik melakukan penelitian yaitu Pengaruh Latihan Senam Aerobic Terhadap Tingkat Kebugaran Jasmani Siswa Putra Kelas VIII SMP Negeri 10 Muaro Jambi, dengan tujuan dari penelitian ini adalah untuk mendapatkan informasi dan mengetahui seberapa besar Pengaruh Latihan Senam Aerobic Terhadap Tingkat Kebugaran Pada Siswa Putra Kelas VIII SMP Negeri 10 Muaro Jambi.

\section{Medode}

Penelitian ini adalah penelitian eksperimen, penelitian ini dilakukan untuk meningkatkan kebugaran siswa. Adapun rancangan penelitian ini merupakan rancangan One Group Pretest-Postest Desigh yaitu kelompok yang diberikan perlakuan, tetapi sebelum perlakuan dilakukan diiiberikan dahulu tes awal (pretest), kemudian diberi perlakuan senam aerobic dan dilakukan lagi test akhir (postest), seperti bagan dibawah ini :

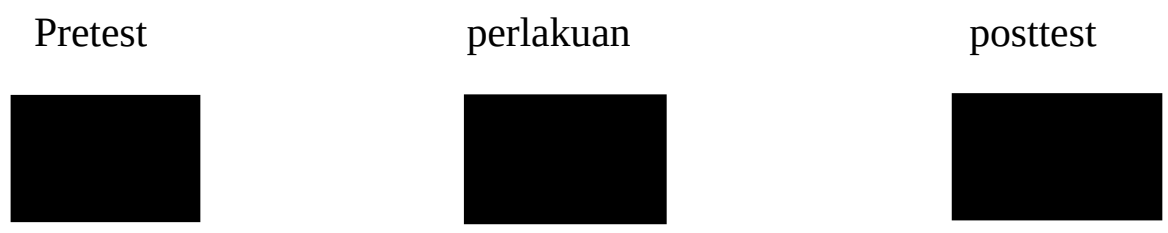

Keterangan :

Y1 : Tes awal (Pretest)

$\mathrm{X} \quad$ : Senam Aerobic

Y2 : Tes akhir

Populasi adalah suatu kumpulan menyeluruh dari suatu objek yang merupakan perhatian penelitian. Populasi diartikan sebagai seluruh anggota kelompok yang telah ditentukan karateristiknya dengan jelas, baik itu kelompok orang, objek, benda atau kejadian.

Dalam sebuah penelitian selalu ada subjek atau objek yang menjadi sasaran penelitian , yang disebut populasi.

Populasi dalam penelitian ini adalah seluruh Siswa SMP Negeri 10 Muaro Jambi Yang Berjumlah 386 siswa

Sampel merupakan sebagian atau wakil populasi yang diteliti. Berpedoman pada gambaran tersebut, maka pengambilan sampel dilakukan secara total sampling. Hal ini dilakukan mengingat jumlah populasi yang relatif kecil, sehingga seluruh populasi diangkat menjadi sampel yaitu seluruh siswa putra Kelas VIII D sebanyak 14 siswa.

Menurut arikunto (2007), Instrumen penelitian adalah alat yang digunakan untuk mengumpulkan data, Penelitian ini menggunakan satu instrumen penelitian yaitu : 1) Tes kebugaran jasmani

Tes yang digunakan dalam penelitian ini antara lain;

1. $\quad$ Lari 50 meter.

2. Tes gantung angkat bahu untuk putra 
IJSSC: Indonesian Journal of Sport Science and Coaching

Vol. 1 No. 1 Febaruari 2019

Available on: https://online-journal.unja.ac.id/IJSSC

3. $\quad$ Baring duduk 60 detik (sit up).

4. Loncat tegak. dan

5. $\quad$ Lari 1000 meter

Data yang diperoleh dari penelitian ini bersumber dari sampel dan diperoleh dari hasil tes TKJI yang terdiri dari lima tes yaitu:

$1 . \quad$ Lari 50 meter.

2. $\quad$ Tes gantung angkat bahu (pul up)

3. $\quad$ Baring duduk (sit up).

4. Loncat tegak. dan

5. Lari 1000 meter berikut:

Adapun langkah-langkah yang dilakukan untuk mendapatkan data penelitian ini yaitu sebagai

1. Sampel dikumpulkan dan di beri pemahaman tentang pelaksanaan pengukuran yang akan dilakukan dan di beri pemahaman tentang tujuan dilakukannya tes TKJI (tes kebugaran jasmani indonesia).

2. Peneliti menyiapkan segala perlengkapan tulis untuk pelaksanaan tes,

3. Peneliti menyiapkan 5 asisten pembantu, satu di tugaskan untung mencatat hasil akhir sampel, dan empat lainnya ditugaskan untuk memperhatihan seluruh sampel yang akan berlari.

4. Peneliti membawa sampel ke tempat garis star. Dan memberi arahan bagai mana pelaksanaan tes

Pelaksanaan dari masing-masing tes tersebut dapat diuraikan sebagai berikut:

\section{Lari 50 meter}

Bertujuan untuk mengukur kecepatan lari. Tes dilakukan pada lintasan yang lurus, datar, rata, tidak licin dan berjarak 50 meter, masih mempunyai lintasan lanjutan. Pelaksanaan dari lintasan tes ini yaitu:

a. Sikap permulaan gerakan

Peserta berdiri dibelakang garis start.

b. Gerakan

1) Pada aba-aba "SIAP” peserta mengambil sikap start siap untuk lari.

2) Pada aba-abaap start siap untuk lari.

3) Pada aba-aba "YA” peserta lari secepat mungkin menuju garis finish.

c. Lari masih bisa diulang apabila

1) Pelari mencuri start

2) Pelari tidak melewati garis finsh

3) Pelari terganggu oleh pelari lain.

d. Pengukuran waktu

Pengukuran waktu dilaksanakan dari saat bendera diangkat sampai pelari melintas garis finish.

e. Pengukuran waktu 
IJSSC: Indonesian Journal of Sport Science and Coaching

Vol. 1 No. 1 Febaruari 2019

Available on: https://online-journal.unja.ac.id/IJSSC

1) Hasil yang dicatat adalah waktu yang dicapai oleh pelari untuk menempuh jarak 50 meter dalam satuan detik.

2) Waktu dicatat satu angka dibelakang koma.

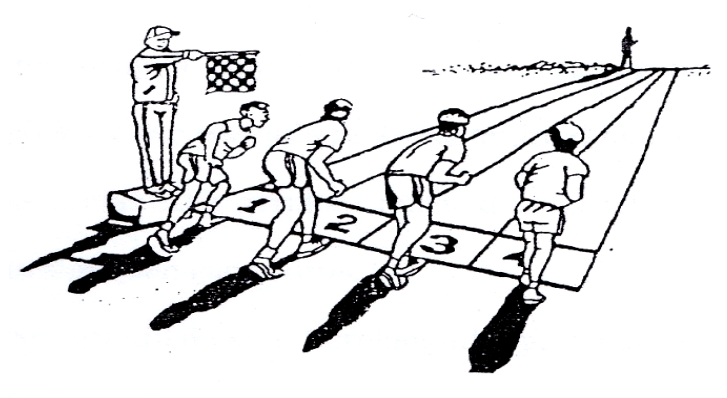

\section{Gambar 1. Posisi start lari 50 meter}

\section{Tes Gantung Angkat Tubuh (60 detik)}

Tujuan dari tes ini adalah untuk mengukur kekuatan dan ketahanan otot lengan dan otot bahu pelaksana tes. Pelaksanaan tes ini:

a. Sikap permulaan

1) Peserta berdiri dibawah palang tunggal, kedua tangan berpegang pada palang tunggal selebar bahu.

2) Pegangan telapak tangan menghadap daerah letak kepala.

b. Gerakan

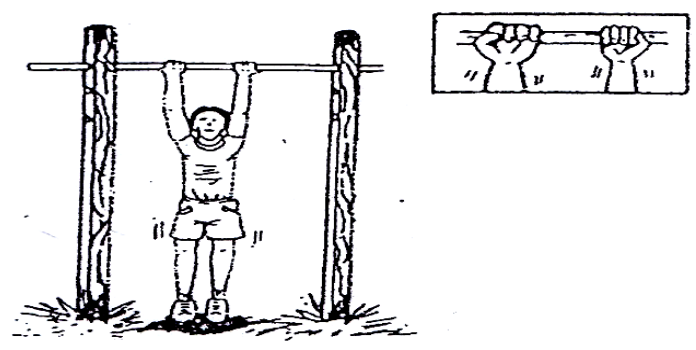

Gambar 2. Sikap Permulaan gantung angkat tubuh putra

1) Mengangkat tubuh dengan membengkokkan kedua lengan sehingga dagu menyentuh atau berada diatas palang tunggal, kemudian kembali kesikap permulaan. Gerakan ini dihitung satu kali.

2) Selama melakukan gerakan mulai dari kepala sampai ujung kaki tetap merupakan garis lurus.

3) Gerakan ini dilakukan berulang-ulang, tanpa istirahat, sebanyak mungkin selama 60 detik.

c. Angkatan dianggap gagal dan tidak dihitung apabila:

1) Pada waktu mengangkat badan, peserta melakukan gerakan mengayung.

2) Pada waktu mengangkat badan, dagu tidak menyentuh palang tunggal.

3) Pada waktu kembali kesikap permulaan kedua lengan tidak lurus. 
IJSSC: Indonesian Journal of Sport Science and Coaching

Vol. 1 No. 1 Febaruari 2019

Available on: https://online-journal.unja.ac.id/IJSSC

d. Pencatat hasil

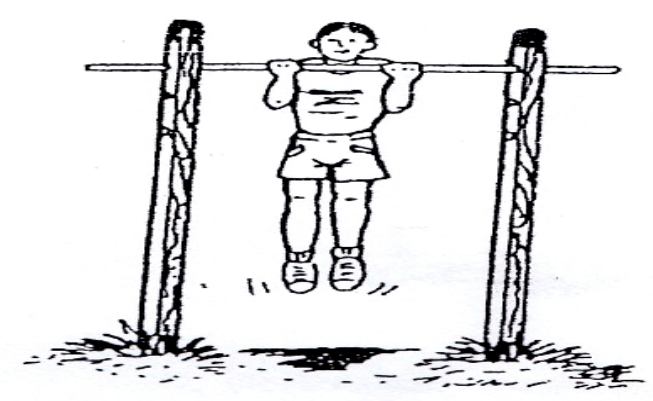

Gambar 3. Sikap dagu menyentuh atau melewati palang tunggal

1) Yang dihitung adalah angkatan yang dilakukan dengan sempurna.

2) Yang dicatat adalah angkatan yang dilakukan dengan sikap sempurna tanpa istirahat selama 60 detik.

\section{Baring duduk 60 detik (sit up)}

Tujuan dari tes ini adalah untuk mengukur kekuatan dan ketahanan otot perut. Pelaksanaannya sebagai berikut:

a. Sikap permulaan

1) Berbaring terlentang di lantai atau tumpu, kedua lutut ditekuk dengan sudut 90 derajat, kedua tangan jarinya berselang seling diletakkan dibelakang kepala.

2) Petugas/peserta lain memegang atau menekan pergelangan kaki agar kaki tidak terangkat.

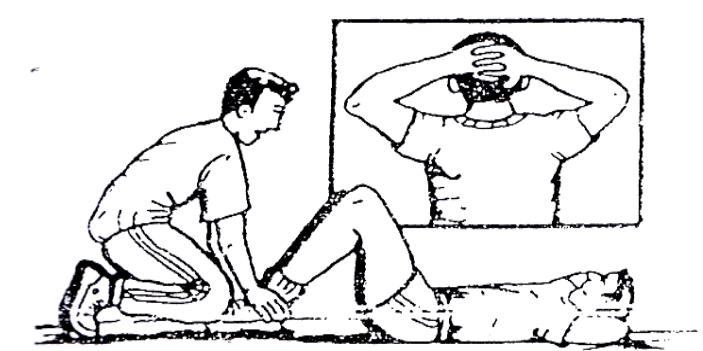

b. Gerakan

Gambar 4. Sikap permulaan baring duduk.

1) Gerakan aba-aba "YA" peserta bergerak mengambil sikap duduk sampai kedua sikunya menyentuh kedua paha, kemudian kembali kesikap permulaan.

2) Gerakan ini dilakukan berulang-ulang dengan cepat tanpa istirahat selama 60 detik.

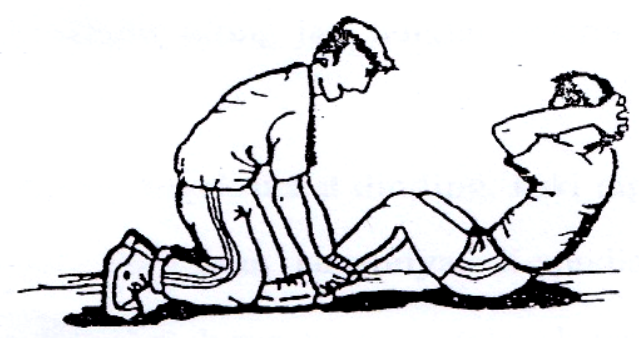


IJSSC: Indonesian Journal of Sport Science and Coaching

Vol. 1 No. 1 Febaruari 2019

Available on: https://online-journal.unja.ac.id/IJSSC

Gambar 5. Gerakan baring menuju sikap duduk

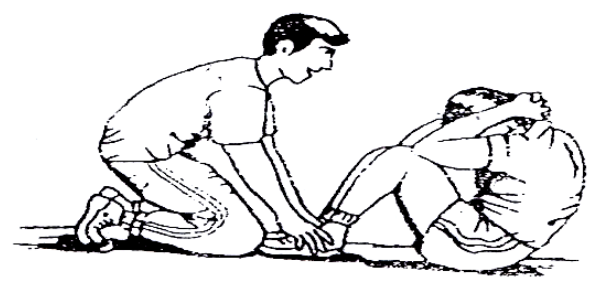

Gambar 6. Gerakan sikap duduk dengan kedua siku menyentuh paha

c. Pencatatan hasil

1) Hasil yang dicatat dan dihitung adalah jumlah gerakan baring duduk yang dapat dilakukan dengan sempurna selama 60 detik.

2) Peserta yang tidak mampu melakukan tes baring duduk ini diberi nilai nol (0).

\section{Loncat Tegak}

Tujuan dari tes loncat tegak ini adalah untuk mengukur power tungkai dalam arah vertikal. Pelaksanaannya sebagai berikut:

a. Sikap permulaan

1) Terlebih dahulu ujung jari tangan peserta diolesi dengan serbuk kapur.

2) Peserta berdiri tegak dekat dinding, kaki rapat, papan skala berada disamping kiri atau kanannya. Kemudian tangan yang dekat dinding

3) diangkat lurus keatas, telapak telapak tangan ditempelkan pada papan skala, sehingga meninggalkan bekas raihan jarinya.

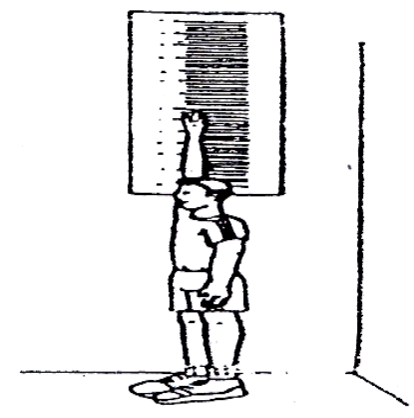

\section{b. Gerakan}

1) Peserta mengambil awalan dengan sikap menekukkan lutut dan kedua lengan diayung kebelakang. Kemudian peserta melompat setinggi mungkin sambil menepuk papan dengan tangan terdekat sehingga menitan bekas.

2) Lakukan tes ini sebanyak tisting oleh peserta lain. 
IJSSC: Indonesian Journal of Sport Science and Coaching

Vol. 1 No. 1 Febaruari 2019

Available on: https://online-journal.unja.ac.id/IJSSC

Gambar 8. Sikap awal loncat tegak

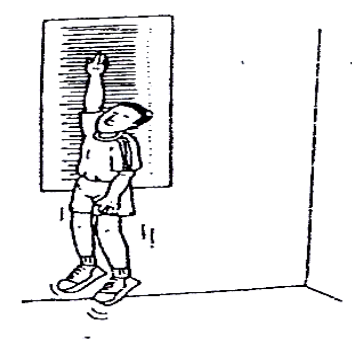

Gambar 9. Gerakan meloncat tegak

c. Pencatatan hasil

1) Selisih raihan loncatan dikurangi raihan tegak.

2) Ketiga selisih raihan dicatat.

\section{Lari 1000 meter}

Tes ini bertujuan untuk mengukur daya tahan jantung, peredaran darah, dan pernafasan. Pelaksanaannya sebagai berikut:

a. Sikap permulaan (Peserta berdiri dibelakang garis start.)

b. Gerakan

1)

berdiri, siap untuk lari.

2)

menempuh jarak 1000 meter.

Pada aba-aba “SIAP” peserta mengambil sikap start Pada aba-aba "YA" peserta lari menuju garis finis,

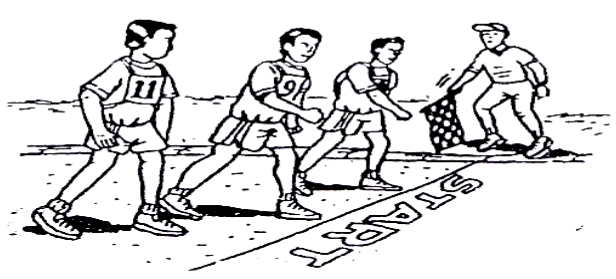


IJSSC: Indonesian Journal of Sport Science and Coaching

Vol. 1 No. 1 Febaruari 2019

Available on: https://online-journal.unja.ac.id/IJSSC

Gambar 10. Posisi start lari 1000 meter

c. Pencatatan hasil

1) Pengambilan waktu dilakukan dari saat bendera diangkat sampai pelari tepat melintas garis finis.

2) Hasil yang dicatat adalah waktu yang dicapai oleh pelari, waktu dicatat dalam satuan menit dan detik.

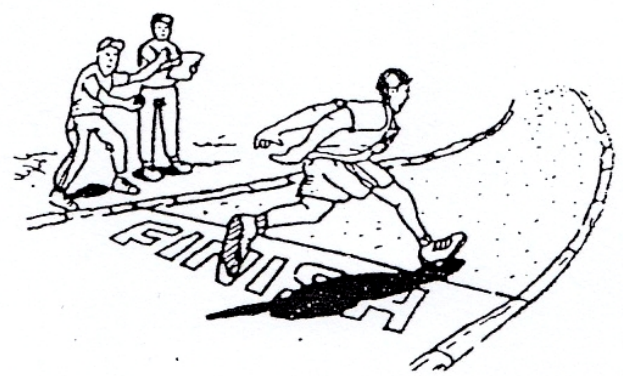

Gambar 11. Stopwatch dimatikan saat pelari melintasi garis finis

Sumber: gambar dalam skripsi Nirgaleni 2008

Tabel Nilai Tes Kesegaran Jasmani Indonesia (Sumber: Arsil, 1999:149)

Tabel 3.1. Nilai Tes Kesegaran Jasmani Indonesia (Untuk Putra Usia 13-15 Tahun)

\begin{tabular}{|c|c|c|c|c|c|c|}
\hline Nilai & $\begin{array}{c}\text { Lari } \\
50 \text { meter }\end{array}$ & $\begin{array}{c}\text { Gantung } \\
\text { angkat tubuh }\end{array}$ & $\begin{array}{l}\text { Baring } \\
\text { duduk }\end{array}$ & $\begin{array}{c}\text { Loncat } \\
\text { tegak }\end{array}$ & $\begin{array}{c}\text { Lari } \\
1000 \text { meter }\end{array}$ & Nilai \\
\hline 5 & S.d - 6,7" & 16 - Keatas & 38 -Keatas & 66 Keatas & s.d - 3' 04" & 5 \\
\hline 4 & 6,8" -7,6" & $11-15$ & $28-37$ & $53-65$ & 3' 05” - 3'53” & 4 \\
\hline 3 & 7,7" -8,7" & $6-10$ & $19-27$ & $42-52$ & 3' 54”- 4'46” & 3 \\
\hline 2 & 8,8"10,3" & $2-5$ & $8-18$ & $31-41$ & 4' 47” - 6'04” & 2 \\
\hline 1 & $10,4 "-d s t$ & $0-1$ & $0-7$ & $0-30$ & 6' 05”- dst & 1 \\
\hline
\end{tabular}

Tabel 1. Normal Tes Kesegaran Jasmani Indonesia

(Untuk Putra dan putri Usia 13-1 5 Tahun)

\begin{tabular}{|c|c|lc|}
\hline No & Jumlah nilai & \multicolumn{2}{|c|}{$\begin{array}{c}\text { Klasifikasi Kesegaran } \\
\text { Jasmani }\end{array}$} \\
\hline 1. & $22-25$ & Baik sekali ( BS ) \\
\hline 2. & $18-21$ & Baik & ( B ) \\
\hline 3. & $14-17$ & Sedang $\quad$ ( S ) \\
\hline 4. & $10-13$ & Kurang $\quad$ ( K ) \\
\hline 5. & $5-9$ & Kurang sekali ( KS ) \\
\hline
\end{tabular}


IJSSC: Indonesian Journal of Sport Science and Coaching

Vol. 1 No. 1 Febaruari 2019

Available on: https://online-journal.unja.ac.id/IJSSC

Untuk memudahkan pengolahan data maka di buat langkah-langkah perhitungan sebagai berikut :

1. Mencari nilai rata-rata pada masing masing variabel setiap data awal dan data akhir, dengan menggunakan rumus sebagai berikut :

$$
\mathrm{Mx}=\frac{\sum x}{n}
$$

Keterangan :

$\mathrm{Mx}=$ nilai rata-rata yang dicari

$\sum \mathrm{x} \quad=$ jumlah skore variabel

$N \quad=$ jumlah sampel

Sumber : Anas Sudijono, 2009:85

2. Mencari nilai simpangan baku dari masing-masing variabel pada tes awal dan tes akhir, meggnakan rumus variansi dan akar variansi adalah nlai simpangan baku dengan rumus sebagai berikut :

$$
\mathrm{S}^{2}=n \sum X^{2}-
$$

Keterangan :

$\begin{array}{ll}\mathrm{S}^{2} & : \text { varisai } \\ \mathrm{n} & \text { : jumlah } \\ \mathrm{n} \sum \mathrm{X}^{2} & : \text { jumlah dari nilai } \mathrm{X}^{2} \text { variabel } \mathrm{X} \text { atau } \mathrm{Y} \\ \sum \mathrm{X} & \text { : jumlah dari variabel } \mathrm{X} \text { atau } \mathrm{Y} \\ \mathrm{n}(\mathrm{n}-1) & : \text { jumalh dikurang b1 derajad kebebasan } \\ \mathrm{S} & \text { : simpangan baku }\end{array}$

Frekuensi data bertujuan untuk menetahui peningkatan distribusi frekuensi, tingkat kebugaran siswa dengan cara membandingkan frekuensi data pre test dan post test.

Uji normalitas yang digunakan adalah uji Lilliefors, sebelum dilakukan uji-t maka terlebih dahulu dilakukan perhitungan normalitas dari setiap data , yang bertujuan untuk mengetahui apakah data tersebut berdistribusi normal atau sebaliknya. Untuk pengujian hipotesis nol, ditempuh dengan prosedur sebagai berikut:

a. $\quad$ Pengamatan $X_{1}, X_{2}$, Dijadikan bilangan baku $Z_{1}, Z_{2}, \ldots \ldots \ldots . ., Z_{n}$ dengan menggunakan rumus: $Z_{1}=\frac{X_{1-\dot{X}}}{S}$

( $X$ dan $\mathrm{S}$ merupakan rata-rata dan simpangan baku setiap variabel tes)

b. Untuk setiap bilangan baku ini, menggunakan daftar distribusi normal baku, kemudian dihitung pula $\mathrm{F}\left(Z_{1}\right)=\mathrm{P}\left(\mathrm{Z} \leq Z_{1}\right)$

c. $\quad$ Kemudian dihitung proporsi $Z_{1}, Z_{2}, \ldots \ldots \ldots . ., Z_{n}$ yang lebih kecil atau sama dengan $Z_{1}$. Jika proporsi ini dinyatakan oleh $S\left(Z_{1}\right)$, maka: 
IJSSC: Indonesian Journal of Sport Science and Coaching

Vol. 1 No. 1 Febaruari 2019

Available on: https://online-journal.unja.ac.id/IJSSC

$$
\mathrm{S}\left(Z_{i}\right)=\frac{\text { banyak nya } Z_{1}, Z_{2}, \ldots . Z_{n}, Z_{i}}{n}
$$

d. Hitung selisih $\mathrm{F}\left(Z_{1}\right)-\mathrm{S}\left(Z_{1}\right)$ kemudian tentukan harga mutlaknya.

e. Hitung harga paling besar diantara harga-harga mutlak selisih tersebut, sebutlah harga ini (Lo).

f. Untuk menerima dan menolak hipotesis nol, maka kita bandingkan Lo ini dengan nilai kritis L yang diambil dari daftar nilai kritis L untuk uji Lilliefors, dengan taraf nyata $\alpha=0,05$. Kriterianya adalah : tolak hipotesis normal berarti data tidak berdistribusi normal sebaliknya terima hipotesis nol berarti data berdistribusi normal. Hipotesis nol berarti $L_{\text {hitung }}$ $L_{\text {tabel }}$.

Uji homogenitas varians bertujuan untuk melihat apakah kedua kelompok mempunyai variansi yang homogen apa tidak. Rumus yang digunakan adalah Uji-F dikatakan homogen apabila $F_{\text {hitung }}<F_{\text {tabel. }}$

Menurut sudjana (2005:249) dijelaskan rumus yang digunakan adalah sebagai berikut:

$$
\mathrm{F}=\frac{S_{2}^{1}}{S_{2}^{2}}
$$

Keterangan :

$S_{2}^{1} \quad$ : Variansi terbesar dari kemampuan daya tahan

$S_{2}^{2} \quad$ : Variansi terkecil dari kemampuan daya tahan

Setelah dilakukan analisis frekuensi, uji normalitas, uji homogenitas varians maka dilakukan uji hipotesis untuk mengetahui apakah gerakan senam aerobik pengaruh Terhadap tingkat kebugaran Pada Siswa putra kelas VIII SMP Negeri 10 Muaro Jambi. Uji hipotesis menggunakan uji t pada taraf kepercayaan 95\% atau $\alpha=0,05$ menurut Sudjana (2005:239) adalah sebagai berikut:

$$
\begin{aligned}
& \mathrm{t}=\frac{M d}{\sqrt{\frac{\sum X^{2} d}{n(n-1)}}} \\
& \text { keterangan : } \\
& \text { Md : mean perbedaan dari tesd awal dan tes akhir } \\
& \mathrm{Xd} \quad \text { : deviasi masing-masing subjek (d-Md) } \\
& \sum \mathrm{X}^{2} \mathrm{~d} \quad \text { : jumlah kuadrat deviasi } \\
& \mathrm{N} \quad \text { : subjek pada asmpel } \\
& \text { Db : :ditentukan dengan n-1 }
\end{aligned}
$$

Dengan hipotesis yang dikemukakan terima Ho berarti tidak ada pengaruh latihan senam aerobik Terhadap tingkat kebugaran Siswa Putra Kelas VIII SMP Negeri 10 Muaro Jambi. Dan tolak Ho terima Ha ada pengaruh gerakan senam aerobik Terhadap Tingkat Kebugaran Siswa Putra Kelas VIII SMP Negeri 10 Muaro Jambi. Untuk lebih Jelasnya adalah sebagai berikut : 
IJSSC: Indonesian Journal of Sport Science and Coaching

Vol. 1 No. 1 Febaruari 2019

Available on: https://online-journal.unja.ac.id/IJSSC

Ho : $\left(X_{1}=X_{2}\right.$ Tidak ada pengaruh gerakan senam aerobik Terhadap Tingkat Kebugaran Siswa Putra Kelas VIII SMP Negeri 10 Muaro Jambi.

Ha : $\left(X_{1} \neq X_{2}\right.$ Ada pengaruh gerakan senam aerobik Terhadap Tingkat Kebugaran Siswa Putra Kelas VIII SMP Negeri 10 Muaro Jambi.

\section{Pembahasan}

Berdasarkan analisis data dan pengujian hipotesis yang digunakan rumus t-test dalam penelitian ini, diharapkan melahirkan suatu kesimpulan yangn sesuai dengan data yang diperoleh. Kesimpulan yanng diperoleh berdasarkan dari data yang diperoleh. Dengan demikina kesimpulan yang diambil merupakan gambaran dari data yang diharapkan selama penelitian dilakukan. Untuk itu pengkajian tentang teori suatu penelitian.

Dalam pelaksanaan penelitian ini, pengambilan data dilakukan sebanyak dua kali pengambilan data pertama dilakukan sebelum sampel di beri perlakuan, sedangkan pengambilan data ke dua dilakukan setelah sampel diberi perlakuan. Penelitian ini bertujuan untuk melihat peningkatan tingkat kebugaran siswa setelah diberi latihan senam aerobic. Pengujian hipotesis dilakukan dengan membandingkan hasil test awal dan test akhir.berdasarkan hasil analisis dari tes awal dan tes akhir di dapat pengaruh yang signifikan melalui Latihan Senam Aerobic Terhadap Tingkat Kebugaran Siswa Putra SMP Negeri 10 Muaro Jambi. Hal ini dibuktikan karena $T_{\text {hitung }}>T_{\text {tabel }}(11,55>1,771)$, maka Ho ditolak dan Ha diterima. Dengan demikian dalam peningkatan kebugaran Siswa SMP Negeri 10 Muaro Jambi Dapat Menggunakan Latihan Senam Aerobic.

\section{Kesimpulan}

Berdasarkan analisis data yang dilakukan, maka hipotesis yang dikemukakan dapat di terima kebenarannya ditinjau dari hasil yang diperoleh dengan nilai rata - rata tingkat kebugaran siswa pada pelaksanaan tes awal adalah 13 dengan kriteria (kurang), setelah diberi perlakuan sebanyak 18 kali, kemudian di lakukan tes akhir sehingga memperoleh hasil dengan nilai rata-rata 17 dengan kriteria (cukup). Dengan demikian dapat disimpulkan bahwa terdapat Pengaruh Latihan Senam Aerobic Terhadap tingkat kebugaran Pada Siswa Putra Kelas VIII SMP Negeri 10 Muaro Jambi.

\section{Daftar Pustaka}

Arikunto.2010. Prosedur Penelitian Suatu Pendekatan praktik. Rineka Cipta. Jakarta Awangga Suryaputra N. 2007. "desain proposal penelitian”. Banguntapan-Bantul- Yogyakarta.

Boy Indrayana,2015.”Panduan Penulisan Skripsi”.FIK UNJA.JAMBI

Dinata, M. 2004. Padat berisi dengan aerobik. Ciputat: Cerdas jaya

Febriana Sartika Sari, Oktavianus. 2014.”Asuhan Keperawatan Pada Sistem Kardiovaskuler Dewasa”. Ruko Jambusari 7A Yogyakarta.

Giri Wiarto. 2013.” ATLETIK. Ruko Jambusari no. 7A Yogyakarta.

Giriwijoy, Y.S.S. dan Sidik, D.Z. 2012. Ilmu kesehatan olahraga.Bandung: PT Remaja Rosdakarya.

http://www.scribd.com/doc/111212923/Contoh-Latihan-Daya-Tahan\#scribd (diakses pada tgl 12 januari 2015) 
IJSSC: Indonesian Journal of Sport Science and Coaching

Vol. 1 No. 1 Febaruari 2019

Available on: https://online-journal.unja.ac.id/IJSSC

http://materipenjasorkes.blogspot.com/2012/11/latihan-daya-tahan-jantung-dan-paru-paru.html akses pada tgl 12 januari 2015)

Irwansyah. 2008.” Pendidikan Jasmani Olahraga dan Kesehatan’. Grafindo Media Pratama. Bandung. Jarver Jess. 2009.’Belajar dan Berlatih Atletik”. CV.PIONIR JAYA Bandung.

Joe Hendenson, Richard L. Brown. 1996.’’Bugar dengan Lari”. PT Raja Grafindo Persada Jakarta.

James Tangkudung. 2006. “'KEPELATIHAN OLAHRAGA, Pembinaan Prestasi Olahraga”. Cerdas Jaya -Pondok Hijau-Ciputat-Jakarta-indonesia.

Junusul. Hairy 2003, Daya Tahan Aerobic.UNP Padang

Karya-ilmiah.um.ac.id/indekx.php/penjaskes/article/view/10579(http://rachmatrindu. blogspot.com/ 2012/04/mengukurkesegaranjasmani.html?m=1).(di akses pada tgl 23 juni 2015)

Mahendra.2001. Pembelajaran Senam. Direktorat Jenderal Olahraga

Muhajir. 2007.” PENDIDIKAN JASMANI OLAHRAGA DAN KESEHATAN”. Ghalia Iundonesia Printing, Bandung Indonesia.

Muhajir. 2006.” Pendidikan Jasmani Olahraga dan Kesehatan’. PT.Yudhistira Ghalia Indonesia. Bandung.

Oktavianus \& Febriana K. 2014.”Sistem Kardiovaskuler Dewasa:.GRAHA ILMU ruko jambusari 7A. Yogyakarta.

Rusbandi Sarpini.2014”Anatomi dan Fisiologi Tubuh Manusia”. IN MEDIA Jakarta.

Syafruddin. 2011. 'ILMU KEPELATIHAN OLAHRAGA, Teori dan Aplikiasinya Dalam Pembinaan Olahraga. UNP Press Padang.

Sugiyono.2013. Metode Penelitian Kuantitatif, Kualitatif Dan R \&D. Alfabeta. Bandung.

Suwandi, Suparno.2008. ”Pendidikan Jsamani Olahraga dan Kesehatan”. PT Bumi Aksara Jakarta.

Widiastuti.2011 “Tes dan Pengukuran Olahraga” Pt Bumi Timur Jaya, Jakatra Timur.

Winarno. 2011. “' Metodologi Penelitian Dalam Pendidikan Jasmani”. Media Cakrawala Utama, MALANG. 